\title{
UPAYA MENINGKATKAN HASIL BELAJAR PESERTA DIDIK DENGAN MENGGUNAKAN MEDIA AUDIO VISUAL PADA PELAJARAN BAHASA INDONESIA KELAS V SDN-5 MENTENG PALANGKA RAYA
}

\author{
Oleh \\ Hendri Gunawan', A'am Rifaldi Khunaifi' \\ Email: aamrifaldikhunaifi@umpalangkaraya.ac.id
}

\begin{abstract}
This study aims to determine whether or not there is an increase in activity and learning outcomes of students in Indonesian language lessons, the subject of listening to population density using audio grade $\mathrm{V}$ media in Menteng-5 Elementary School Palangkaraya. The research method used in this study is the Classroom Action Research (CAR) method. With the number of research subjects 28 students. There was an increase in the activity of students when the learning process of Indonesian Language especially listening to a news using Audio Visual media in class V students of SDN-5 Menteng Palangkaraya this was evidenced by the results of the average activity of students namely 3.65 while the average activity teacher is 3.64 . There has been an increase in learning outcomes after being distributed using audio visual media listening to news on Indonesian language lessons for students in fifth grade of Menteng-5 SDN Palangkaraya. This can be seen from the learning outcomes of students, in the first cycle that is 73.03 and the classical completeness is $60.71 \%$ and in the second cycle it increases to 81.25 and the classical completeness is $100 \%$.
\end{abstract}

(C) Muhammadiyah University of Palangkaraya

Keywords: Audio Visual media and learning outcomes

\begin{abstract}
ABSTRAK
Penelitian ini bertujuan untuk mengetahui ada atau tidaknya peningkatan aktivitas dan hasil belajar peserta didik dalam pelajaran Bahasa Indonesia pokok bahasan menyimak kepadatan penduduk dengan menggunakan media audio kelas V SDN -5 Menteng Palangkaraya. Metode penelitian yang digunakan dalam penelitian ini adalah metode Penelitian Tindakan Kelas (PTK). Dengan jumlah subjek penelitian 28 orang peserta didik. Ada peningkatan aktivitas peserta didik pada saat proses pembelajaran Bahasa Indonesia khususnya menyimak sebuah berita dengan menggunakan media Audio Visual pada peserta didik kelas V SDN -5 Menteng Palangkaraya hal ini dibuktikan dengan hasil rata-rata aktivitas peserta didik yaitu 3,65 sedangkan rata-rata aktivitas guru yaitu 3,64. Ada peningkatan hasil belaiar setelah dizqarkan menggunakan media audio visual menyimak sebuah berita pada pelajaran Bahasa Indonesia pada peserta didik kelas V SDN -5 Menteng Palangkaraya. Hal ini terlihat dari hasil belajar peserta didik, pada siklus I yaitu 73,03 dan ketuntasan secara klasikalnya yaitu 60,71\% dan pada siklus II meningkat menjadi 81,25 dan ketuntasan klasikalnya yaitu $100 \%$.
\end{abstract}

(C) Universitas Muhammadiyah Palangkaraya

Kata Kunci: Media Audio Visual dan hasil belajar.

Hendri Gunawan Universitas Muhammadiyah Palangkaraya 


\section{PENDAHULUAN}

Pendidikan merupakan proses untuk mencetak generasi suatu bangsa dengan proses belajar mengajar yang merupakan aktivitas paling penting sehingga melalui proses itulah tujuan pendidikan tercapai dalam bentuk perubahan perilaku peserta didik. Selama ini pemerintah berusaha memberikan perhatian terhadap masalah-masalah dalam bidang pendidikan yang diimplementasikan dengan menuangkan dalam Undang Undang Nomor 20 Tahun 2003 tentang Sistem Pendidikan Nasional dalam pasal 3 yang menjelaskan fungsi dan tujuan Pendidikan Nasional sebagai berikut:

Pendidikan nasional berfungsi mengembangkan kemampuan dan membentuk watak serta bangsa yang bermartabat dalam rangka mencerdaskan kehidupan bangsa, bertujuan berkembangnya potensi peserta didik agar menjadi manusia yang beriman dan bertakwa kepada Tuhan Yang Maha Esa, berakhlak mulia, sehat, berilmu, cakap, kreatif. Mandiri dan menjadi warga negara yang demokratis serta bertanggung jawab.

Pelajaran Bahasa Indonesia merupakan pelajaran pokok dimana pelajaran Bahasa Indonesia didapatkan mulai dari kelas 1 sampai kelas VI, dalam pelajaran Bahasa Indonesia tidak lepas dengan empat keterampilan dasar berbahasa yaitu membaca, menulis, mendengarkan menyimak dan berbicara. menyimak merupakan suatu keterampilan yang harus diperhatikan karena melalui menyimak dapat menerima informasi atau pelajaran dengan benar. Dalam pelajaran Bahasa Indonesia Peserta didik dituntut untuk memahami empat keterampilan berbahasa yang mana salah satunya adalah keterampilan menyimak keterampilan menyimak wajib dipelajari Peserta didik agar dapat menyimak pembelajaran dengan tepat.

Melalui Bahasa Indonesia seorang guru melatih Peserta didiknya menggunakan bahasa sejak anak duduk dijenjang pendidikan dasar dengan demikian anak sudah dibekali keterampilan berbahasa Indonesia, sehingga nanti akhirnya anak mampu mempunyai kemampuan menyimak dari suatu kejadian yang didapat. Dengan memiliki kemampuan menyimak sebuah berita atau informasi serta pelajaran yang diberikan guru maka akan berpengaruh kepada hasil belajar Peserta didik nantinya.

Menurut pendapat Higart (Abin S Makmun 2012:157) berpendapat bahwa "belajar adalah suatu perubahan prilaku atau pribadi seseorang berdasarkan praktik atau pengalaman tertentu".

Sedangkan menurut Nana Syaodih Sukmadinata menyatakan bahwa Hasil belajar merupakan realisasi atau pemekaran dari kecakapan-kecakapan potensial atau kapasitas yang dimiliki seseorang". Penguasaan hasil belajar oleh seseorang dapat dilihat dari prilakunya, baik prilaku dalam bentuk penguasaan, pengetahuan, keterampilan berpikir maupun keterampilan motorik.

Menurut Oka (Mansur Muslich2009: 24) Bahasa Indonesia adalah mata pelajaran yang wajib diberikan dari jenjang sekolah dasar sampai dengan perguruan tinggi, hal itu 
karena bahasa Indonesia merupakan bahasa nasional sekaligus bahasa Negara di Indonesia.

Menurut Yunus Abidin (2012:14) menyatakan bahwa: "Berdasarkan kurikulum tingkat Satuan Pendidikan (KTSP) mata pelajaran Bahasa Indonesia bertujuan agar peserta didik memiliki kemampuan sebagai berikut".

1. Berkomunikasi secara efektif dan efesien sesuai dengan etika yang berlaku, baik secara lisan maupun tertulis.

2. Menghargai dan bangga menggunakan bahasa Indonesia sebagai bahasa persatuan dan bahasaNegara.

3. Memahami bahasa Indonesia dan menggunakannya dengan tepat dan kreatif untuk berbagai tujuan.

Menggunakan bahasa Indonesia untuk meningkatkan kemampuan intelektual, serta kematangan emosional dan sosial. Menikmati dan memanfaatkan karya sasta untuk memperluas wawasan, memperhalus budi perkerti, serta meningkatkan pengetahuan dan kemampuan berbahasa.

Menurut Brooks (Henry Guntur Tarigan hal 2008 : 3) berpendapat "bahwa menyimak dan berbicara merupakan kegiatan komunikasi dua arah secara langsung, merupakan komunikasi tatap muka atau face of face communication".

Menurut Tarigan (Henry Guntur Tarigan 2008: 65) mengatakan bahwa Tujuan utama pengajaran bahasa ialah agar para siswa terampil berbahasa, dalam pengertian terampil menyimak, terampil bebicara, terampil menulis dan terampil membaca

Menurut E. kosasih (2007:161) "Berita adalah peristiwa atau kejadian yang telah dilaporkan. Berita bersifat faktual dan pada umumnya menyangkut peristiwa atau kejadian yang aktual dan menarik perhatian khalayak". Dan khalayak itu dapat diartikan sebagai masyarakat umum jadi berita itu adalah suatu kejadian yang dilaporkan dengan sesuai apa adanya tanpa adanya penambahan dalam penyampaian sebuah informasi yang disampaikan kepada sipenerima informasi tersebut.

Menurut pendapat Gerlach dan Ely (Rodhatul Jennah 2009 :1) mengatakan bahwa: "Media apabila dipahami secara garis besar adalah manusia, materi, atau kejadian yang membangun kondisi yang membuat siswa mampu memperoleh pengetahuan dan keterampilan, atau sikap. Dalam pengertian ini guru, buku teks, dan lingkungan sekolah merupakan media".

Menurut Rodhatul Jenaah (2009:48) macam-macam media pembelajaran yang terdiri dari:

1. Media visual yaitu media yang pesannya hanya dapat diamati dengan indra penglihatan.media ini merupakan jenis media yang mempunyai informasi secara visual,tetapi tidak dapat menampilkan suara maupun gerak misalnya gambar, foto, grafik dan poster.

2. Media audio yaitu media yang menghasilkan pesan hanya dengan suara saja,jenis media ini hanya memanipulasi kemampuankemapuan suara semata-mata, 
misalnya radio, tape recorder, laboratorium bahasa.

3. Media audio visual media pembelajaran ini disebut juga dengan media audio visual.media audio visual juga dapat didefinisikan sebagai media yang dapat menghasilkan pesan,yang kesannya dapat dilihat dan didengar.media ini merupakan media yang paling lengkap karena menggunakan kemampuan media audio visual dan gerak yang termasuk media audo visual misalnya: televisi vidio,proyektor flim bersuara,slide suara.

\section{METODE PENELITIAN}

Dalam penelitian ini metode yang sesuai digunakan untuk meningkatkan hasil belajar peserta didik yaitu penelitian tindakan kelas. Menurut Hopkins (Masnur Muslich, 2009: 8) berpendapat bahwa PTK itu adalah suatu bentuk kajian yang bersifat reflektif, yang dilakukan oleh pelaku tindakan untuk meningkatkan kemantapan rasional dari tindakantindakannya dalam melaksanakan tugas dan memperdalam pemahaman terhadap kondisi dalam praktik pembelajaran.

Subjek penelitian pada penelitian tindakan kelas ini adalah seluruh peserta didik kelas V SDN-5 Menteng Palangkaraya seperti dijelaskan pada tabel berikut:

\begin{tabular}{|c|c|c|}
\hline No & $\begin{array}{c}\text { Jenis Kelamin } \\
\text { Peserta Didik }\end{array}$ & $\begin{array}{c}\text { Jumlah } \\
\text { Peserta Didik }\end{array}$ \\
\hline 1 & Laki-laki & 15 \\
\hline 2 & Perempuan & 12 \\
\hline \multicolumn{2}{|c|}{ Jumlah } & 27 \\
\hline
\end{tabular}

Dalam penelitian ini dikumpulkan menggunakan observasi dan tes, observasi digunakan untuk mengumpulakan data tentang kegiatan peserta didik dalam proses belajar mengajar, tes digunakan untuk mendapatkan fakta, pendapat,dan kemampuan peserta didik selam kegiatan menyimak sebuah berita dalam pelajaran Bahasa Indonesia.

Menurut Sugiyono (2008: 56) menyatakan bahwa: Penelitian kombinasi (mixed methods) adalah suatu penelitian yang mengkombinasikan atau menggabungkan antara metode kualitatif dan metode kuantitatif untuk digunakan secara bersama-sama dalam kegiatan penelitian, sehingga diperoleh data yang lebih komprehensip, valid, liale dan objektif.

Data kuantitatif berasal dari pre test yang dilakukan sebelum pembelajaran dan post test yang dilakukan diakhir pembelajaran

Data kualitatif diperoleh dari lembar observasi yang dimaksudkan untuk mengetahui kelebihan dan kekurangan pembelajaran yang dilakukan. Data kualitatif diperoleh dari aktivitas peserta didik dan gurudalam proses pembelajaran dengan menganalisis keaktifan peserta didik dan keefektifan pembelajaran yang dikelola guru/peneliti dalam menyimak melalui berita.

\section{HASIL DAN PEMBAHASAN}

Pada tahap ini peneliti melaksanakan tindakan pembelajaran menggunakan Media Audio Visual pada pelajaran bahasa Indonesia. 
1. Pengamatan aktivitas guru dan peserta didik, Aktivitas guru dan peserta didik dapat dilihat pada tabel dan gambar berikut :

\section{Tabel 1}

Aktivitas Guru dan Peserta Didik

\begin{tabular}{|l|l|c|c|}
\hline No & Aktivitas & $\begin{array}{c}\text { Siklus } \\
\text { I }\end{array}$ & $\begin{array}{c}\text { Siklus } \\
\text { n }\end{array}$ \\
\hline 1 & $\begin{array}{l}\text { Peserta } \\
\text { Didik }\end{array}$ & 2,55 & 3,65 \\
\hline 2 & Guru & 2,64 & 3,64 \\
\hline
\end{tabular}

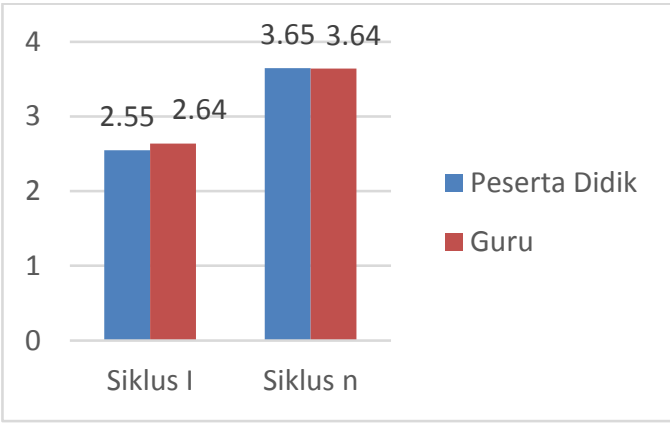

Gambar 1

Grafik Aktivitas Guru dan Peserta Didik

Dari data di atas maka dapat diketahui bahwa aktivitas guru dan peserta didik mengalami peningkatan disetiap siklusnya. Hal tersebut menunjukkan bahwa penggunaan Model Media Audio Visual dapat digunakan dan tepat agar peserta didik aktif dalam proses pembelajaran.

2. Hasil belajar yang diperoleh berdasarkan hasil tes pada peserta didik Media Audio Visual.

Tabel 2

Nilai Hasil Belajar Peserta Didik

\begin{tabular}{|l|l|c|c|}
\hline \multirow{2}{*}{ No. } & \multicolumn{3}{|c|}{ Hasil Belajar } \\
\cline { 2 - 4 } & Nilai & $\begin{array}{c}\text { Rata- } \\
\text { rata }\end{array}$ & Ketuntasan \\
\hline 1. & Siklus I & 73,03 & 60,71 \\
\hline 2. & $\begin{array}{l}\text { Siklus } \\
\mathrm{n}\end{array}$ & 81,25 & 100 \\
\hline
\end{tabular}

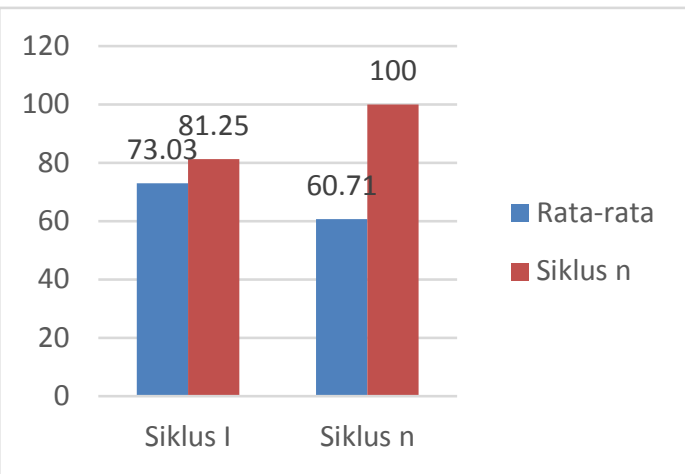

Gambar 2.

Grafik Rata-rata Hasil Belajar Peserta Didik

Berdasarkan tabel dan grafik di atas maka dapat diketahui bahwa hasil belajar peserta didik mengalami peningkatan pada setiap siklusnya. Hal tersebut menunjukkan bahwa penggunaan Media Audio Visual dapat digunakan dan tepat untuk meningkatkan hasil belajar peserta didik.

\section{KESIMPULAN}

Aktivitas belajar menyimak berita pada peserta didik kelas V di SDN-5 Menteng Palangkaraya dengan menggunakan media audio visual lebih aktif. Peserta didik menjadi sering bertanya, mendengarkan berita dengan sungguh-sungguh serta menjadi fokus dalam belajar menyimak berita atau informasi. Aktivitas peserta didik pada siklus I memperoleh rata-rata 25,5 dengan kriteria cukup baik dan meningkat di siklus $\mathrm{n}$ dengan rata-rata 3,65 dengan kriteria baik.

Peningkatan hasil belajar menyimak berita pada peserta didik kelas V SDN-5 Menteng Palangkaraya meningkat dengan menggunakan media 
audio visual Pada perolehan hasil pre tes, 16 dari 28 orang peserta didik yang tidak tuntas atau hanya ada 35,71\% yang tuntas dalam menyimak berita ditunjukkan dengan nilai rata-rata 60,17 .Kemudian siklus I ketuntasannya meningkat menjadi $60,71 \%$ atau 17 dari 28 orang peserta didik tidak tuntas dalam post tes awal (siklus I) dengan nilai rata-rata73,03 dan post tes kedua (siklus $\mathrm{n}$ ) seluruh peserta didik kelas $\mathrm{V}$ SDN -5 Menteng tuntas dengan pencapaian ketuntasan klasikal 100\% dan rata-rata nilai 81,25 .

\section{DAFTAR PUSTAKA}

Abidin Yunus, 2012, Pembelajaran Bahasa Indonesia Pendidikan Karakter, Bandung: PT. Refika Aditama

E.Kosasih.2007, Bahasa Indonesia Untuk, SMA: Bandung Yrama Widya
Makmun Abin Syamsuddin, 2012, Psikologi Kependidikan, Bandung: PT. Remaja Rosdakarya

Muslich Masnur, 2009, Melaksanakan PTK Itu Mudah, Jakarta: Bumi Aksara

Rodhatul Jennah, 2009, Media Pembelajaran, Banjarmasin Antasari Pers

Sugiyono, 2008, Metode Penelitian Pendidikan, Bandung: Alfabeta

Sukmadinata. Nana Syaodih, 2004 Landasan Psikologis Proses Pendidikan. Bandung: PT Remja Rosdakarya

Tarigan Henry Guntur, 2008, Menyimak Sebagai Suatu Keterampilan Berbahasa, Bandung: Angkasa Bandung. 